RPP-RPT-54608, Rev. 0

\title{
Needs Analysis for Dimethyl Mercury
}

Author Name:

Michael J. Schmoldt

Richland, WA 99352

U.S. Department of Energy Contract DE-AC27-08RV14800

EDT/ECN: DRF UC

Cost Center: $\quad$ Charge Code: BW 2/13/13

B\&R Code: $\quad$ Total Pages: 15 H4

Key Words: Dimethyl Mercury, Exposure Assessment

Abstract: For this needs analysis, a total of $131 \mathrm{DMHg}$ analytical results were collected and reviewed from the Hanford Tank Farms from 2004 to 2007. Sampling data from the Site Wide Industrial Hygiene Database (SWIHD), the Tank waste Inventory System (TWINs), and prior sampling campaigns by CH2M Hill Hanford that were not available in the SWIHD database, were aggregated for analysis. Technical literature used by the Savannah River Site (SRS), Bechtel RPP-WTP, and CH2M Hill Hanford from 2003 2007, were also reviewed to identify potential DMHg exposure concerns applicable to the tank farms. After analyzing the adequacy of the data, information gaps were identified and recommendations for corrective actions items were developed.

TRADEMARK DISCLAIMER. Reference herein to any specific commercial product, process, or service by trade name, trademark, manufacturer, or otherwise, does not necessarily constitute or imply its endorsement, recommendation, or favoring by the United States Government or any agency thereof or its contractors or subcontractors.

APPROVED

By G. E. Bratton at 3:17 pm, Feb 13, 2013

Release Approval

Date

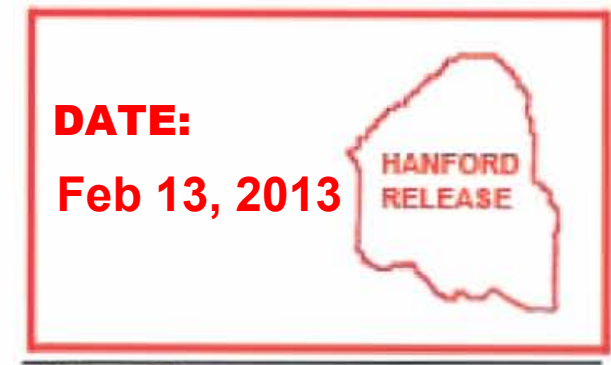

Release Stamp

\section{Approved For Public Release}




\section{Table of Contents}

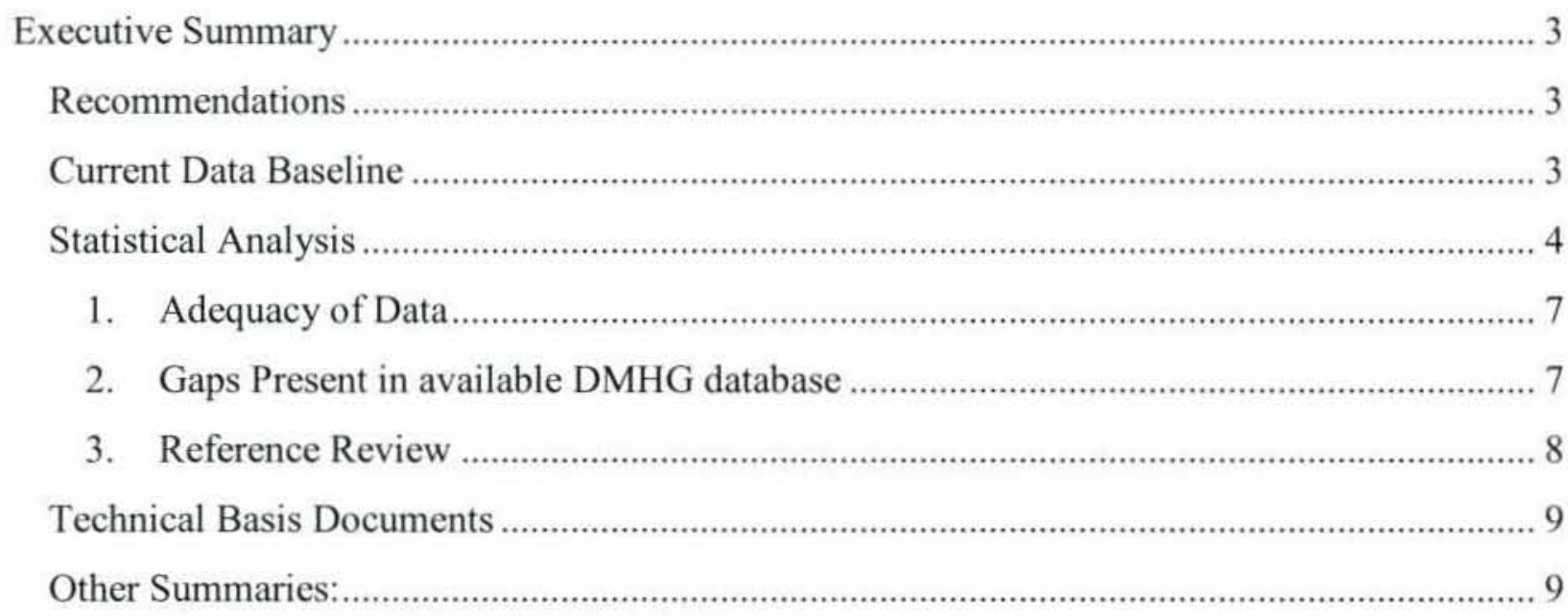

Table 1 IH-DA Statistical Results for DMHg Exposure Assessment........................................... 6

Graph 1 Di-Methyl Mercury Milligrams per cubic meter ………….......................................... 5

Attachments 1 Tank Farm DMHG Industrial Hygiene Sampling (2004-2007) ........................... 9

Attachments 2 TWINS Tank Farm DMHg Headspace Sampling (2004-2005) ............................ 9 


\section{Needs Analysis for Dimethyl Mercury \\ RPP-RPT-54608, Rev. 0}

\section{Executive Summary}

This report was prepared in response to the October 2012, letter from the U.S. Department of Energy, Office of River Protection (DOE-ORP), referencing Report S-12-SHD Tankfarm-012: Validity of Di Methyl Mercury (DMHg or DMM) Exposure Data. The response to this inquiry resulted in Corrective Action WRPS-PER-2012-1736.

For this needs analysis, a total of $131 \mathrm{DMHg}$ analytical results were collected and reviewed from the Hanford Tank Farms from 2004 to 2007. Sampling data from the Site Wide Industrial Hygiene Database (SWIHD), the Tank waste Inventory System (TWINs), and prior sampling campaigns by $\mathrm{CH} 2 \mathrm{M}$ Hill Hanford ${ }^{i}$ that were not available in the SWIHD database, were aggregated for analysis. Technical literature used by the Savannah River Site (SRS), Bechtel RPP-WTP, and CH2M Hill Hanford from 2003-2007, were also reviewed to identify potential $\mathrm{DMHg}$ exposure concerns applicable to the tank farms. After analyzing the adequacy of the data, information gaps were identified and recommendations for corrective actions items were developed.

\section{Recommendations}

a) Develop a DMHg specific assessment strategy to: Continue verifying baseline source data, define Similar Exposure Groups (SEGs), prioritize sampling efforts, analyze and document exposure assessment results. (WRPS PER-0075)

b) Develop a laboratory subcontract agreement for additional $\mathrm{DMHg}$ verification sampling (WRPS PER-0077)

c) Prepare data quality objectives and a written plan for DMHg sampling and sampling documentation to verify the quality of the sampling and analytical data. (WRPS PER-0078)

d) Evaluate making program modifications to the SWIHDs software to re- calculate sample volume based on the highest sample volume measure when results are $>10 \%$ different during post-calibration. (WRPS PER-0079)

\section{Current Data Baseline}

The Industrial Hygiene Chemical Vapor Technical Basis for 2005 added DMHg to the chemicals of potential concern (COPC) list:

".. because it had recently been detected for the first time in the tanks, and its maximum headspace concentration was considered too uncertain to omit it from the COPC list. "

The address this COPC, a total of 131 carbotrap samples of DMHG were collected for analysis by Frontier Geosciences between 2004 and 2007. These samples were collected from Tanks: C 104, C 107 and C 202 headspaces and area samples were collected from other locations near: A, AN, AP, SY, AR-204, as well as from the 242-A evaporator source and area samples. 


\section{Needs Analysis for Dimethyl Mercury \\ RPP-RPT-54608, Rev. 0}

Samples were collected according to written sampling plans

${ }^{23} 45$ which identified the procedures for collecting and special handling of the laboratory samples for submittal. Sampling plans included requirements for media protection from sunlight after collecting samples, by wrapping in aluminum foil, drying of traps, field and trip blank directions and chain of custody information requirements were described in the sampling plans.

Chain of custody logs list the time and date samples were submitted from field to laboratory for analysis. The Carbotrap media is prone to accumulating water vapor during air sampling, which frequently results in air flow decrease of more than $10 \%$ during pump post calibration. For samples where the post calibration flow is $>10 \%$ less than pre-calibration values, results can be recalculated using the conservative method, described in the OSHA Technical manual, of using the lower volume value to calculate the entire time period.

This is not the default calculation in Site Wide Industrial Hygiene Database System (SWIHDs) which calculates the average value from pre and post calibration data. Laboratory reports from Frontier Geosicences document test results as well as QA testing, flags and any qualifications about samples identified by the laboratory.

A COC comment on flow rates was resolved as an observation between the calibrated flow rate and the flow indicating rotometer on the sample pump.

In verbal interviews with an Industrial Hygienist involved in the sampling, the reason for discontinuing sampling was based on reviewing the SRS data and determining that the smaller quantities of total mercury present made the reaction kinetics for levels as high as those observed at SRS unlikely. A correlation with total mercury and measured DMHG values was developed and seemed to be verified by observations of the predicted lower headspace concentrations. According to interviews with some IH's involved in the sampling, due to priorities at the time, this correlation analysis was relied upon, but was undocumented. ${ }^{6}$

The strategy for gathering the data was based on previous studies that elemental mercury concentrations would be proportional to the potential for DMHG formation. Tanks with the highest mercury content were selected for headspace analysis and limited sampling was done on the headspace of other selected tanks. Headspace and area samples were collected since levels were likely to be detected by the analytical method chosen. Personal samples were not collected due to the expectation that $\mathrm{DMHg}$ would not be detectable after dilution from the source into the breathing zone.

\section{Statistical Analysis}

The median value for DMHg from the 131 samples was $1 \mathrm{e}-6 \mathrm{mg} / \mathrm{m}^{3}$ with a maximum value of $2.5 \mathrm{e}-4 \mathrm{mg} / \mathrm{m}^{3}$. Of the 126 samples analyzed, only 30 were reported as greater than the analytical limit of detection. The analytical results reported are all two orders of magnitude below the Occupational Exposure Limit (OEL), of $0.1 \mathrm{mg} / \mathrm{m}^{3}$, which places them well below both the action limit and administrative controls limits. Graph 1 shows the distribution of data.

Page $\mathbf{4}$ of $\mathbf{1 0}$ 
Graph 1

Di-Methyl Mercury Milligrams per cubic meter

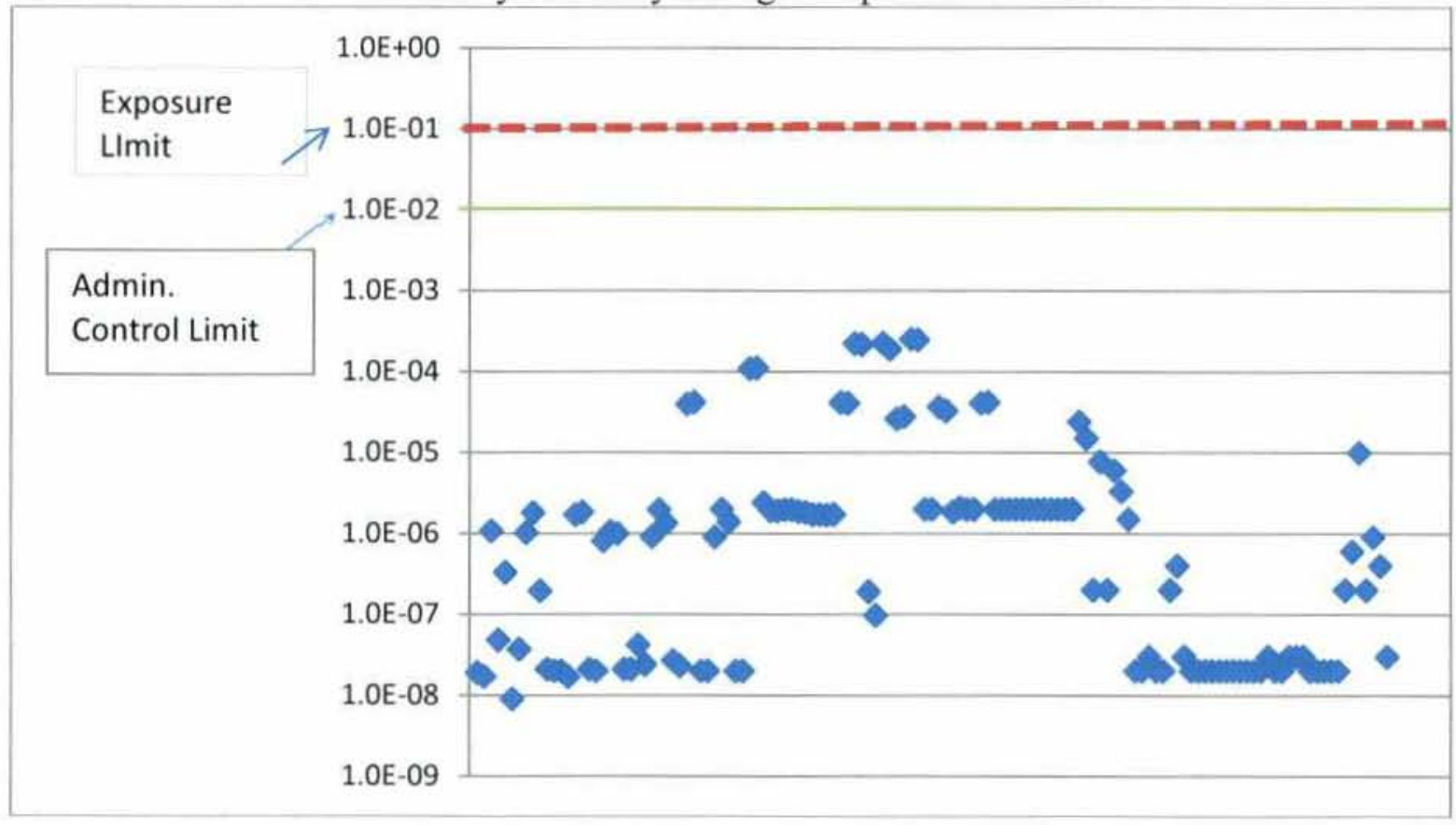

Attachment 1 summarizes the DMHg data in the SWIHD system. Information collected in 2004 and from the 2004 242-A Evaporator Campaign area samples. This adds 94 datapoints which were not in the SWIHDs database. Attachment 2 summarizes the DMHG data from the TWINS database.

The locations where more than 2 samples were taken were analyzed using the Industrial Hygiene-Data Analyst (IOH-DA) software developed by Dr. Paul Hewett who was formerly with National Institute of Safety and Health (NIOSH). The results are summarized in Table 1 below. Highest results were from double shell tanks primary exhauster samples in C tanks breather filters and the AW and AP tank stacks. 
Table 1

IH-DA Statistical Results for DMHg Exposure Assessment

(grey shaded values are in $\mathrm{mg} / \mathrm{m}^{3}$ )

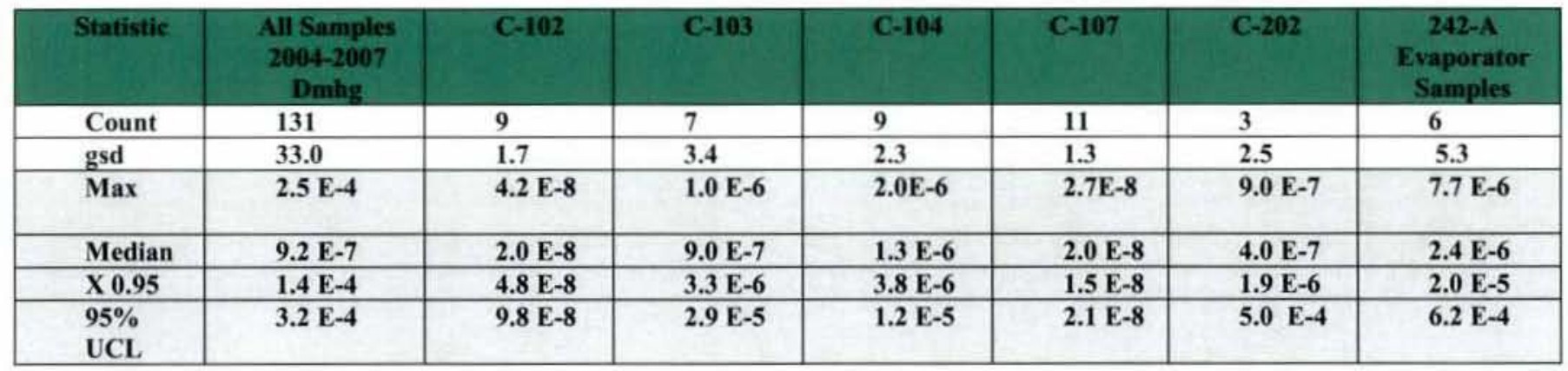

For defining Similar Exposure Groups (SEGs) a geometric standard deviation (gsd) of $<3$ is usually applied for using the AIHA risk assessment strategy. Grouping all the samples as one SEG, shown in column 2 of Table 1, does not make sense since the gsd is large. When more similar exposures are measured, the SEG is considered to be validated if the gsd $<3$; if it is not $<3$, either the exposure group needs further separation or additional samples to confirm or deny the hypothesis that this a SEG are necessary.

Further confirmation is provided by evaluating the $95 \%$ percentile (X0.95) estimated concentration and the upper confident limit (UCL) for the $95 \%$ percentile values. If these values are below the OEL, then the SEG exposure profile is considered well controlled as evidenced by statistical confirmation.

For C-102, C-104, C-107 and C-202 -sufficient data is present to verify the that the headspace acts like a SEG over time based on the low gsd and calculated exposure estimates for X0.95 and $95 \%$ UCL being below both the OEL and ACL. For C-103 and 242-A evaporator samples, the gsd is $>3.0$, but the DMHg values are still low. C-103 and the 242-A evaporators samples are cases where a few additional samples would be helpful to better characterize the tank statistically, but given the low measurements, the degree of uncertainty that exposure above the action limit is still low and further sampling would useful primarily for periodic verification.

Some qualifications of individual results based on gaps in Chain of Custody documentation, review of laboratory quality assurance (QA) and other factors may be necessary, but decisions supported by multiple samples, over time, with sufficient statistical control are unlikely to be significantly altered.

Recognizing the additional complexity of sampling for DMHG, critical controls for sample QA should be clearly identified in the sampling plan and documented in Chain of Custody (COC) documents. 


\section{Adequacy of Data}

The Tank Waste Inventory Network System lists the Best-Basis Summary for elemental Mercury in each tank. The estimated inventory of elemental mercury was the 'best basis' for identifying tanks where elemental mercury quantities were highest and therefore where there was the most potential for formation and subsequent exposure to $\mathrm{DMHg}$.

Sampling for DMHg over a 3-year period, in a variety of tanks and areas, did not find concentrations approaching the OEL, or even $10 \%$ of the Administrative Control Limit (ACL). Subsequent statistical evaluation showed that the X0.95 confidence interval and $95 \% \mathrm{UCL}$ highest values were also well below the OEL.

Personal sampling data has not been collected since $\mathrm{DMHg}$ levels were expected to be too low to detect. The levels in headspace samples were above detection limits frequently enough so that the data was not too heavily censored to perform statistical analysis. All of the area samples are below the detection limits. $100 \%$ censored data can still be useful to measure variability and verify maximum potential exposures, but provides less of a basis for statistical analysis in establishing similar exposure groups.

Skin exposure data was not directly collected, but the 2007 studies evaluating the potential for dermal exposure based on conservative estimates of $\mathrm{DMHg}$ present in condensed water or organic vapors, concluded that the dermal exposure hazard form tank waste chemicals was extremely low and required no additional controls. With the lower levels of DMHg encountered, the dermal assessment is still valid.

\section{Gaps Present in available DMHG database}

Data quality for samples collected in 2004-2007 for DMHg cannot be comprehensively verified due to the time that has passed, turn-over of personnel, contractor transition and changes in the documentation captured in the current database. No systemic errors were identified based on the detailed sampling plans, available Frontier Geosciences analytical reports or chain of custody documentation. Not all sampling prior to 2005 had complete records that could be located. For example, the chain of custody documentation does not address protecting samples from UV light (although this was discussed in the sampling plans). Questions raised during DOE-ORP interviews with $\mathrm{IH}$ technicians about past practices for temperature control, holding times, how long it took to perform radiological clearance to release samples and recovery of $\mathrm{DMHg}$ relative to elemental $\mathrm{Hg}$ and total $\mathrm{Hg}$ should be considered as concerns when planning future sampling campaigns and the corresponding data quality objectives and documentation requirements.

Multiple samples based on a strategy that allows for statistical validation is desirable when practical. Where two or fewer chemical samples are present, statistical validation using methods such as calculating the $95 \%$ confidence interval are not always possible. Alternate methods such as Bayesian statistical analysis or grouping additional data from similar sources are possible, but have not been used in the past. Where 2 or fewer samples are available, the higher uncertainty present can't be reduced without additional sampling or additional types of evaluations. 


\section{Needs Analysis for Dimethyl Mercury \\ RPP-RPT-54608, Rev. 0}

Personal exposure SEGs cannot be established, since personal sampling was not measured and are unlikely to be high enough to detect under current conditions. Given the low levels of DMHg present in headspace samples, the development of analogous source SEGS, rather than personal SEGs, is a practical approach. As additional DMHg sources, such as the evaporator operations are sampled, then further definition of source level SEGS or workers SEGs will be possible.

The available data is specific to the conditions of the tanks at the time the samples were collected. Additional data collection should be guided by the AIHA strategy for exposure assessment which focuses on identifying areas where uncertainty in risk assessment exists and where potential for approaching exposure limits are statistically probable. Decisions on similar exposure group exposure potential rely less on a single data point to draw conclusions and are less susceptible to bias. When sufficient data is available, pursuing the AIHA exposure assessment strategy and using statistical analysis can result in less uncertainty and higher confidence the exposure assessments are valid.

\section{Reference Review}

The following documents, technical basis and summary documents contain the basis relied upon for decision making about $\mathrm{DMHg}$ exposure risk.

a) Evaluation of Potential for Chemical Formation of Dimethyl Mercury at High $\mathrm{pH}$ in the Presence of Selected Organics in Collaboration with Frontier Geosciences-Final Report. S.W. Rosencrance. Jan 16, 2003.

b) Risk Response Report for Formation of Hazardous Mercury Compounds (Dimethyl Mercury) in Evaporator Overheads. Dave Harty Oct 31, 2003. CCN 074276.

c) Review of Potential Dimethyl Mercury Exposures. Westinghouse Savannah River Company. David G. Hoel. Feb 4, 2004.

d) Studies of Mercury in High Level Waste Systems. W.R. Wilmath. March 31, 2004. WRSRC-TR-2003-00238 Rev 1.

e) Potential Dimethylmercury Concentration in Water and Organic Condensates. L.M. Stock. CH2M Hill Hanford Group. Inc. December 2004. RPP-RPT-23696 Rev. 0.

f) Concentrations of Chemical of Potential Concern in Water and Organic Condensates. CH2M Hill Hanford Group. Inc. L. M. Stock April 2004. RPP-RPT-24794 Rev. 0.

g) Action Item for C-Farm Pilot. From: Technical Basis Strategic Planning. CH2M Hill Hanford Group, Inc. 7F700-04-001. 6/25/2004.

h) Industrial Hygiene Conclusion Report for the 242-A Evaporator Campaign 05-01. CH2M Hill Hanford Group, Inc. August 25, 2005. 7T800-05-JAR-001-R.

i) Mercury and Dimethylmercury Exposure and Effects. J.O. Honeyman CH2M Hill Hanford Group, Inc. RPP-RPT-26633. 12/13/2005. Rev 0.

j) Concentrations of Chemical of Potential Concern in Water and Organic Condensates. CH2M Hill Hanford Group. Inc. J.E. Meacham March, 2006. RPP-RPT-24794. Rev. 1.

k) Tank Waste Dermal Exposure Assessment. CH2M Hill Hanford Group. Inc. T. J. Anderson. June 2007. RPP-34147 Rev. 0.

Page 8 of 10 


\section{Needs Analysis for Dimethyl Mercury}

RPP-RPT-54608, Rev. 0

1) SRNL Letter "Input for Dimethylmercury formation and partitioning. August 20, 2007. T.J. Valenti. CCN: 160522.:

m) Preliminary Engineering Assessment of Dimethyl mercury formation and emissions in PTF processes. Dec 11, 2007. Thomas Valenti. CCN 1567376.

n) Impacts to WTP Process Models due to pretreatment Dimethylmercury generation. May 4, 2010. Jake E. Vermaas. CCN 1195033.

o) Estimated Concentration of Dimethylmercury in WTP Process Streams. Calculation Sheet. Bechtel RPP-WTP PDC. Matt Gebhardt. June 15, 2010.

\section{Technical Basis Documents}

a) Industrial Hygiene Chemical Vapor Technical Basis (Tech Basis) Rev 0. Oct. 2004, RPP-22491

b) Industrial Hygiene Chemical Vapor Technical Basis (Tech Basis) Rev 1, May, 2006, RPP-22491

Attachments 1 Tank Farm DMHG Industrial Hygiene Sampling (2004-2007)

Attachments 2 TWINS Tank Farm DMHg Headspace Sampling (2004-2005)

\section{Other Summaries:}

These documents contain either summaries of documents above or general information on processes which are relevant to mercury and potential to produce organic mercury compounds.

a) 24590-WTP_BEAT-SA-10-101. General Ambient Chronic Exposure to Di-Methyl Mercury. Sept 29, 2010.

b) 24590-WTP-BEAP-SA-09-100. Updated Qualitative Exposure Assessments for WTP Process Chemicals High Level Waste (HLW), Revision 1, July 20, 2010.

c) 24590-WTP-BEAT-SA-09-100. Updated Qualitative Exposure Assessments for WTP Process Chemicals - Low Activity Waste, Revision 1. July 20, 2010.

d) 24590-WTP-BEATP-SA-09-103. Updated Qualitative Exposure Assessments for WTP Process Chemicals -Pretreatment Facility. Revision 1. July 20, 2010.

e) DOE-012. U.S. Department of Energy (DOE) Risk Assessment Sheet: Formation of Hazardous Mercury Compounds (Di-Methyl Mercury) in Evaporator Overheads. Dec. 9. 2002.

f) DOE-011. DOE Risk Assessment Sheet: HLW Recycle Results in Unacceptable Mercury Emissions. Jan. 19, 2005.

g) 09-WTP-171. Review of the HLW Facility Melter Off-Gas Treatment Process System (A-09-WED-RPPWTP-RPT-005). Sept. 3, 2009. 
${ }^{1}$ Industrial Hygiene Conclusion Report for the 242-A Evaporator Campaign 05-01. CH2M Hill memo from Environmental Health Programs. 7T800-05-JAR-001-R. 8/25/05.

${ }^{2}$ IH Sample Plan at AW and AP Tank Farms for 05-01 Campaign. CH2M Hill memo from WFO Safety \& Health. 7T800-05-JAR-002 Rev.2 2/28/05.

${ }^{3}$ Sample Strategy and letter of Instruction for Sampling of Tank Headspace Rev 7 July 9, 2004 by WFO Safety and Health 7b100-o4-PKA-015 R7.

${ }^{4}$ Letter of Instruction for Sampling and Analysis for Mercury in 242-A Evaporator Campaign 05-01 Process Condensate. Memo from Process/Waste Transfer Engineering. CH2M Hill Hanford Group. Inc. Feb 4, 2005. 7G230-05-TMH-005.

${ }^{5}$ A-Complex Mercury Vapor Characterization Sampling Plan. Memo from Environmental Health. Nov. 22, 2004. Note: similar plans were documented for: S-Complex March 6, 2006, C-Complex March 3, 2006, T-Farm Complex June 8, 2006, U-Farm June 8, 2006 and for tank C202 July 24, 2007.

${ }^{6}$ Email from Michael Zabel to Michael Schmoldt 2/6/2013

Attachment 1. Tank Farm DMHG Industrial Hygiene Sampling (2004-2007)

Attachment 2 TWINS Tank Farm DMHg Headspace Sampling (2004-2005) 
Tank Farm DMHg Industrial Hygiene Sampling (2004-2007)

RPP-RPT-54608 Attachment 1

\begin{tabular}{|c|c|c|c|c|c|c|c|}
\hline Survey ID & Survey Date & Sample Number & Specific Location & Other & Range & Air Conc & $\begin{array}{l}\text { Air Conc } \\
\text { UOM }\end{array}$ \\
\hline DMHG-302 & $9 / 1 / 2004$ & $042112-c 102-030$ & C 102 & Breather Filter Sampling & $<$ & 0.000000019 & $\mathrm{mg} / \mathrm{m3}$ \\
\hline DMHg-133 & $9 / 1 / 2004$ & 042116-C102-133 & C 102 & Breather Filter Sampling & $<$ & 0.000000017 & $\mathrm{mg} / \mathrm{m3}$ \\
\hline DMHg-124 & $9 / 1 / 2004$ & 042117-C103-124 & C 103 & Breather Filter Sampling & & 0.000001070 & $\mathrm{mg} / \mathrm{m} 3$ \\
\hline DMHg-303 & $9 / 1 / 2004$ & 042113-C103-031 & C 103 & Breather Filter Sampling & & 0.000000048 & $\mathrm{mg} / \mathrm{m} 3$ \\
\hline DMHg-307 & $9 / 1 / 2004$ & 041124-c104-032 & C 104 & Breather Filter Sampling & & 0.000000330 & $\mathrm{mg} / \mathrm{m3}$ \\
\hline DMHg-309 & $9 / 1 / 2004$ & 042115-C107-033 & C 107 & Breather Filter Sampling & $<$ & 0.000000009 & $\mathrm{mg} / \mathrm{m} 3$ \\
\hline D27 & $9 / 2 / 2004$ & $042120-C 102-210$ & C 102 & Breather Filter Sampling & & 0.000000037 & $\mathrm{mg} / \mathrm{m} 3$ \\
\hline DMHg-127 & $9 / 2 / 2004$ & 042121-C103-127 & C 103 & Breather Filter Sampling & & 0.000001020 & $\mathrm{mg} / \mathrm{m} 3$ \\
\hline $\mathrm{D} 28$ & $9 / 2 / 2004$ & 042122-C104-211 & C 104 & Breather Filter Sampling & & 0.000001810 & $\mathrm{mg} / \mathrm{m3}$ \\
\hline $\mathrm{DMHg}-126$ & $9 / 2 / 2004$ & 042118-C104-126 & C 104 & Breather Filter Sampling & & 0.000000195 & $\mathrm{mg} / \mathrm{m} 3$ \\
\hline DMHg-125 & $9 / 2 / 2004$ & 042123-C107-125 & C 107 & Breather Filter Sampling & $<$ & 0.000000021 & $\mathrm{mg} / \mathrm{m} 3$ \\
\hline DMHg-129 & $9 / 2 / 2004$ & 042123-C107-002 & C 107 & Breather Filter Sampling & $<$ & 0.000000020 & $\mathrm{mg} / \mathrm{m} 3$ \\
\hline DMHG-130 & $9 / 2 / 2004$ & 042123-C107-003 & C 107 & Breather Filter Sampling & $<$ & 0.000000020 & $\mathrm{mg} / \mathrm{m3}$ \\
\hline DMHg-129 & $9 / 2 / 2004$ & 042119-C107-122 & C 107 & Breather Filter Sampling & $<$ & 0.000000017 & $\mathrm{mg} / \mathrm{m} 3$ \\
\hline $\mathrm{DMHg}-128$ & $9 / 14 / 2004$ & 042134-C102-003 & C 102 & Breather Filter Sampling & $<$ & 0.000000021 & $\mathrm{mg} / \mathrm{m} 3$ \\
\hline DMHg-136 & $9 / 14 / 2004$ & 042134-C102-001 & C 102 & Breather Filter Sampling & & 0.000000020 & $\mathrm{mg} / \mathrm{m} 3$ \\
\hline DMHg-121 & $9 / 14 / 2004$ & 042135-C103-001 & C 103 & Breather Filter Sampling & & 0.000000807 & $\mathrm{mg} / \mathrm{m3}$ \\
\hline DMHg-116 & $9 / 14 / 2004$ & 042136-C104-001 & C 104 & Breather Filter Sampling & & 0.000001063 & $\mathrm{mg} / \mathrm{m3}$ \\
\hline DMHg-137 & $9 / 14 / 2004$ & 042136-C104-003 & C 104 & Breather Filter Sampling & & 0.000000997 & $\mathrm{mg} / \mathrm{m} 3$ \\
\hline DMHg-131 & $9 / 14 / 2004$ & 042137-C107-01 & C 107 & Breather Filter Sampling & $<$ & 0.000000021 & $\mathrm{mg} / \mathrm{m3}$ \\
\hline DMHg-118 & $9 / 14 / 2004$ & 042137-C107-03 & C 107 & Breather Filter Sampling & $<$ & 0.000000021 & $\mathrm{mg} / \mathrm{m} 3$ \\
\hline DMHg-140 & $9 / 20 / 2004$ & 042138-C102-003 & C 102 & Breather Filter Sampling & & 0.000000042 & $\mathrm{mg} / \mathrm{m3}$ \\
\hline DMHg-117 & $9 / 20 / 2004$ & 042138-C102-001 & C 102 & Breather Filter Sampling & $<$ & 0.000000024 & $\mathrm{mg} / \mathrm{m3}$ \\
\hline DMHg-139 & $9 / 20 / 2004$ & 042139-C103-001 & C 103 & Breather Filter Sampling & & 0.000000918 & $\mathrm{mg} / \mathrm{m} 3$ \\
\hline DMHg-123 & $9 / 20 / 2004$ & 042140-C104-003 & C 104 & Breather Filter Sampling & & 0.000001976 & $\mathrm{mg} / \mathrm{m} 3$ \\
\hline DMHg-138 & $9 / 20 / 2004$ & 042140-C104-001 & C 104 & Breather Filter Sampling & & 0.000001347 & $\mathrm{mg} / \mathrm{m3}$ \\
\hline DMHG-119 & $9 / 20 / 2004$ & 042141-C107-001 & C 107 & Breather Filter Sampling & $<$ & 0.000000027 & $\mathrm{mg} / \mathrm{m3}$ \\
\hline DMHg-134 & $9 / 20 / 2004$ & 042141-C107-003 & C 107 & Breather Filter Sampling & $<$ & 0.000000023 & $\mathrm{mg} / \mathrm{m} 3$ \\
\hline DMHg-160 & $9 / 21 / 2004$ & 042144-C102-001 & C 102 & Breather Filter Sampling & $<$ & 0.000000020 & $\mathrm{mg} / \mathrm{m} 3$ \\
\hline
\end{tabular}


Tank Farm DMHg Industrial Hygiene Sampling (2004-2007)

Attachment 1

\begin{tabular}{|c|c|c|c|c|c|c|c|}
\hline Survey ID & Survey Date & Sample Number & Specific Location & Other & Range & Air Conc & $\begin{array}{l}\text { Air Conc } \\
\text { UOM }\end{array}$ \\
\hline DMHg-141 & $9 / 21 / 2004$ & 042144-C102-003 & C 102 & Breather Filter Sampling & $<$ & 0.000000020 & $\mathrm{mg} / \mathrm{m} 3$ \\
\hline DMHG-192 & $9 / 21 / 2004$ & 042145-C103-001 & C 103 & Breather Filter Sampling & & 0.000000904 & $\mathrm{mg} / \mathrm{m} 3$ \\
\hline DMHg-212 & $9 / 21 / 2004$ & 042146-C104-003 & C 104 & Breather Filter Sampling & & 0.000002002 & $\mathrm{mg} / \mathrm{m} 3$ \\
\hline DMHg-195 & $9 / 21 / 2004$ & 042146-C104-001 & C 104 & Breather Filter Sampling & & 0.000001392 & $\mathrm{mg} / \mathrm{m} 3$ \\
\hline DMHg-041 & $9 / 21 / 2004$ & 042147-C107-001 & C 107 & Breather Filter Sampling & $<$ & 0.000000020 & $\mathrm{mg} / \mathrm{m} 3$ \\
\hline DMHg-182 & $9 / 21 / 2004$ & 042147-C107-003 & C 107 & Breather Filter Sampling & $<$ & 0.000000020 & $\mathrm{mg} / \mathrm{m} 3$ \\
\hline $05-0326$ & $3 / 8 / 2005$ & 050326-RDG-001 & AP Stack & Stack & $<$ & 0.000000201 & $\mathrm{mg} / \mathrm{m} 3$ \\
\hline $05-0385$ & $3 / 21 / 2005$ & 050385-JRS-001 & $242-A$ & Area Sampling Basement & $<$ & 0.000000030 & $\mathrm{mg} / \mathrm{m} 3$ \\
\hline $05-0386$ & $3 / 21 / 2005$ & 050386-JRS-001 & $242-A$ & Area Sampling 3rd Floor & $<$ & 0.000000020 & $\mathrm{mg} / \mathrm{m} 3$ \\
\hline $05-0387$ & $3 / 21 / 2005$ & 050387-JRS-001 & $242-A$ & Area Sampling 5th Floor & $<$ & 0.000000020 & $\mathrm{mg} / \mathrm{m} 3$ \\
\hline $05-0384$ & $3 / 21 / 2005$ & 050384-JRS-001 & 242-A Stack & Stack & & 0.000007700 & $\mathrm{mg} / \mathrm{m} 3$ \\
\hline $05-0988$ & $3 / 22 / 2005$ & 050988-KAG-001 & 242-A stack & Stack & & 0.000000130 & $\mathrm{mg} / \mathrm{m} 3$ \\
\hline 05-1003 & $3 / 24 / 2005$ & 051003-KAG-001 & $242 \mathrm{~A}$ & Condenser Room in basement & $<$ & 0.000000020 & $\mathrm{mg} / \mathrm{m} 3$ \\
\hline $05-1004$ & $3 / 24 / 2005$ & 051004-KAG-001 & $242 \mathrm{~A}$ & Condenser Room 5th floor & $<$ & 0.000000020 & $\mathrm{mg} / \mathrm{m} 3$ \\
\hline $05-x x x x x$ & $3 / 24 / 2005$ & AW-Stack & AW Stack & Stack & $<$ & 0.000006000 & $\mathrm{mg} / \mathrm{m} 3$ \\
\hline 05-1006 & $3 / 25 / 2005$ & 051006-SS-001 & AP Stack & Stack & & 0.000001490 & $\mathrm{mg} / \mathrm{m} 3$ \\
\hline 05-1007 & $3 / 28 / 2005$ & 051007-RDG-001 & AP Stack & Stack & & 0.000003350 & $\mathrm{mg} / \mathrm{m} 3$ \\
\hline 05-01294 & $4 / 26 / 2005$ & 05-01294-1-001 & AP Primary Exhauster & stack & $<$ & 0.000000200 & $\mathrm{mg} / \mathrm{m} 3$ \\
\hline $05-01295$ & $4 / 28 / 2005$ & 05-01295-1-001 & SY PRIMARY EXHAUSTER & Readings at SY Stack from manifold. & & 0.000000400 & $\mathrm{mg} / \mathrm{m} 3$ \\
\hline $05-01480$ & $5 / 24 / 2005$ & $05-01480-2-004$ & $702 \mathrm{AZ}$ & OHL12 Base of 702-AZ & $<$ & 0.000000030 & $\mathrm{mg} / \mathrm{m} 3$ \\
\hline $05-01483$ & $5 / 24 / 2005$ & $05-01483-2-004$ & Outside A Farm & $\begin{array}{l}\text { OHG12 Corner of } 4 \text { th St and Buffalo } \\
\text { Ave }\end{array}$ & $<$ & 0.000000020 & $\mathrm{mg} / \mathrm{m} 3$ \\
\hline $05-01474$ & $5 / 24 / 2005$ & $05-01474-2-004$ & Outside A Farm & OLL12 East of A Farm & $<$ & 0.000000020 & $\mathrm{mg} / \mathrm{m} 3$ \\
\hline $05-01482$ & $5 / 24 / 2005$ & $05-01482-2-004$ & Outside AN Farm & $\begin{array}{l}\text { OHG11 Corner of 7th St and Buffalo } \\
\text { Ave }\end{array}$ & $<$ & 0.000000020 & $\mathrm{mg} / \mathrm{m} 3$ \\
\hline $05-01479$ & $5 / 24 / 2005$ & 05-01479-2-004 & Outside AN Farm & OHL11 East Fence of AN Farm & $<$ & 0.000000020 & $\mathrm{mg} / \mathrm{m} 3$ \\
\hline 05-01476 & $5 / 24 / 2005$ & $05-01476-2-004$ & Outside AN Farm & OLG11 Northeast of AN Farm & $<$ & 0.000000020 & $\mathrm{mg} / \mathrm{m} 3$ \\
\hline $05-01477$ & $5 / 24 / 2005$ & $05-01477-2-004$ & Outside AN Farm & OLG12 Norhteast Corner of AN Farm & $<$ & 0.000000020 & $\mathrm{mg} / \mathrm{m} 3$ \\
\hline 05-01473 & $5 / 24 / 2005$ & 05-01473-2-004 & Outside AN Farm & OLL11 East of AN Farm & $<$ & 0.000000020 & $\mathrm{mg} / \mathrm{m3}$ \\
\hline
\end{tabular}

Source: IDMS and SWIHD

$02 / 13 / 2013$ 
Tank Farm DMHg Industrial Hygiene Sampling (2004-2007)

Attachment 1

\begin{tabular}{|c|c|c|c|c|c|c|c|}
\hline Survey ID & Survey Date & Sample Number & Specific Location & Other & Range & Air Conc & $\begin{array}{l}\text { Air Conc } \\
\text { UOM }\end{array}$ \\
\hline 05-01475 & $5 / 24 / 2005$ & 05-01475-2-004 & Outside AN Farm & OLL13 North Of AN Farm & $<$ & 0.000000020 & $\mathrm{mg} / \mathrm{m} 3$ \\
\hline 05-01484 & $5 / 24 / 2005$ & 05-01484-2-004 & Outside AW Farm & OHG13 South 272-AW on 4th St Loop & $<$ & 0.000000020 & $\mathrm{mg} / \mathrm{m} 3$ \\
\hline 05-01481 & $5 / 24 / 2005$ & 05-01481-2-004 & Outside AY Farm & OHL13 AY Change Trailer & $<$ & 0.000000020 & $\mathrm{mg} / \mathrm{m} 3$ \\
\hline $05-01478$ & $5 / 24 / 2005$ & $05-01478-2-004$ & Outside C Farm & OLG13 Between C and AN Farm & $<$ & 0.000000020 & $\mathrm{mg} / \mathrm{m} 3$ \\
\hline $05-01607$ & $6 / 10 / 2005$ & $05-01607-2-004$ & 204AR & OHL 22 E OF 204AR & $<$ & 0.000000030 & $\mathrm{mg} / \mathrm{m} 3$ \\
\hline $05-01606$ & $6 / 10 / 2005$ & $05-01606-2-004$ & 204AR & OHG22 BEHIND 204-AR & $<$ & 0.000000020 & $\mathrm{mg} / \mathrm{m} 3$ \\
\hline $05-01605$ & $6 / 10 / 2005$ & $05-01605-2-004$ & 244-AR & OHL21 NE CORNER OF 244-AR & $<$ & 0.000000020 & $\mathrm{mg} / \mathrm{m} 3$ \\
\hline $05-01610$ & $6 / 10 / 2005$ & 05-01610-2-004 & 272-AW & OHL23 N OF 272-AW & $<$ & 0.000000030 & $\mathrm{mg} / \mathrm{m} 3$ \\
\hline $05-01614$ & $6 / 10 / 2005$ & 05-01614-2-004 & AP Farm & OLG23 NE AP FARM & $<$ & 0.000000030 & $\mathrm{mg} / \mathrm{m} 3$ \\
\hline $05-01612$ & $6 / 10 / 2005$ & $05-01612-2-004$ & AW Farm & OLL21 SW CORNER OF AW FARM & $<$ & 0.000000030 & $\mathrm{mg} / \mathrm{m} 3$ \\
\hline 05-01609 & $6 / 10 / 2005$ & 05-01609-2-004 & Inside A Farm & OLL 22 N 242-A & $<$ & 0.000000020 & $\mathrm{mg} / \mathrm{m} 3$ \\
\hline $05-01615$ & $6 / 10 / 2005$ & $05-01615-2-004$ & Outside A Farm & OLG22 E OF A FARM & $<$ & 0.000000020 & $\mathrm{mg} / \mathrm{m} 3$ \\
\hline $05-01613$ & $6 / 10 / 2005$ & $05-01613-2-004$ & Outside AP Farm & OLL23 E OF AP FARM & $<$ & 0.000000020 & $\mathrm{mg} / \mathrm{m} 3$ \\
\hline $05-01616$ & $6 / 10 / 2005$ & 05-01616-2-004 & Outside AX Farm & OLG21 E OF AX FARM & $<$ & 0.000000020 & $\mathrm{mg} / \mathrm{m} 3$ \\
\hline $05-01602$ & $6 / 10 / 2005$ & $05-01602-2-004$ & Outside AY Farm & $\begin{array}{l}\text { OHG21 ACROSS FROM AY CHANGE } \\
\text { TRAILER }\end{array}$ & $<$ & 0.000000020 & $\mathrm{mg} / \mathrm{m} 3$ \\
\hline $05-01723$ & $6 / 16 / 2005$ & $05-01723-2-002$ & $702 \mathrm{AZ}$ & Stack & $<$ & 0.000000200 & $\mathrm{mg} / \mathrm{m} 3$ \\
\hline $05-01788$ & $6 / 23 / 2005$ & $05-01788-2-002$ & AP Primary Exhauster & stack & & 0.000000600 & $\mathrm{mg} / \mathrm{m} 3$ \\
\hline $05-01853$ & $7 / 6 / 2005$ & 05-01853-2-DMHG & AW PRIMARY EXHAUSTER & & & 0.000010000 & $\mathrm{mg} / \mathrm{m} 3$ \\
\hline $05-10642$ & $11 / 6 / 2005$ & $05-10642-2-014$ & C 103 & $\begin{array}{l}\text { POR-008 Sample Port \#POR-008-VTP- } \\
\text { V-167 }\end{array}$ & $<$ & 0.000000200 & $\mathrm{mg} / \mathrm{m} 3$ \\
\hline $07-02107$ & $8 / 14 / 2007$ & $07-02107-2-002$ & C 202 & Breather Filter & & 0.000000900 & $\mathrm{mg} / \mathrm{m} 3$ \\
\hline $07-02108$ & $8 / 15 / 2007$ & $07-02108-2-002$ & C 202 & Breather Filter & & 0.000000400 & $\mathrm{mg} / \mathrm{m} 3$ \\
\hline $07-02109$ & $8 / 20 / 2007$ & $07-02109-2-002$ & C 202 & Breather Filter & $<$ & 0.000000030 & $\mathrm{mg} / \mathrm{m} 3$ \\
\hline
\end{tabular}


Tank Farm DMHg Headspace Sampling (2004-2005) RPP-RPT-54608 Attachment 2

\begin{tabular}{|c|c|c|c|c|c|c|c|}
\hline Field Sample Id & Lab Sample ID & Sample Date & Tank Name & Sample Type & Range & Air Conc & UOM \\
\hline S30.1-5DM & DMHg-473 & $02 / 01 / 05$ & 241-S-101 & Headspace Sample & $<$ & 0.00000186 & $\mathrm{mg} / \mathrm{m} 3$ \\
\hline S31.1-5DM & $\mathrm{DMHg}-471$ & $02 / 04 / 05$ & 241-S-103 & Headspace Sample & $<$ & 0.00000200 & $\mathrm{mg} / \mathrm{m} 3$ \\
\hline S29.1-5DM & DMHg-438 & $02 / 07 / 05$ & 241-S-107 & Headspace Sample & $<$ & 0.00004100 & $\mathrm{mg} / \mathrm{m} 3$ \\
\hline S30.1.4DM & DMHg-435 & $02 / 01 / 05$ & 241-S-101 & Headspace Sample & $<$ & 0.00000209 & $\mathrm{mg} / \mathrm{m} 3$ \\
\hline S17-1DM & DMHg-301 & $09 / 22 / 04$ & 241-C-107 & Headspace Sample & $<$ & 0.00000242 & $\mathrm{mg} / \mathrm{m} 3$ \\
\hline S17-2DM & DMHg-308 & $09 / 22 / 04$ & 241-C-107 & Headspace Sample & $<$ & 0.00000191 & $\mathrm{mg} / \mathrm{m} 3$ \\
\hline S17-3DM & DMHg-304 & $09 / 22 / 04$ & 241-C-107 & Headspace Sample & $<$ & 0.00000191 & $\mathrm{mg} / \mathrm{m} 3$ \\
\hline 043257-RDM-001 & DMHg-305 & $12 / 02 / 04$ & AN Ventilation & Headspace Sample & $<$ & 0.00000019 & $\mathrm{mg} / \mathrm{m} 3$ \\
\hline Samp14-7DM & DMHg-101 & $09 / 07 / 04$ & 241-C-109 & Headspace Sample & $<$ & 0.00000171 & $\mathrm{mg} / \mathrm{m} 3$ \\
\hline Samp14-8DM & DMHg-102 & 09/07/04 & 241-C-109 & Headspace Sample & $<$ & 0.00000185 & $\mathrm{mg} / \mathrm{m} 3$ \\
\hline S16-1DM & DMHg-110 & $09 / 21 / 04$ & 241-C-104 & Headspace Sample & $<$ & 0.00010900 & $\mathrm{mg} / \mathrm{m} 3$ \\
\hline S16-2DM & DMHg-111 & $09 / 21 / 04$ & 241-C-104 & Headspace Sample & $<$ & 0.00011100 & $\mathrm{mg} / \mathrm{m} 3$ \\
\hline S15-1DM & DMHg-105 & $09 / 20 / 04$ & 241-C-103 & Headspace Sample & $<$ & 0.00003970 & $\mathrm{mg} / \mathrm{m} 3$ \\
\hline S15-2DM & DMHg-106 & $09 / 20 / 04$ & 241-C-103 & Headspace Sample & $<$ & 0.00004200 & $\mathrm{mg} / \mathrm{m3}$ \\
\hline S21.1-4DM & DMHg-418 & $11 / 23 / 04$ & 241-U-204 & Headspace Sample & $<$ & 0.00000171 & $\mathrm{mg} / \mathrm{m3}$ \\
\hline S21.1-5DM & DMHg-417 & $11 / 23 / 04$ & $241-U-204$ & Headspace Sample & $<$ & 0.00000171 & $\mathrm{mg} / \mathrm{m} 3$ \\
\hline S23.1-4DM & DMHg-421 & $11 / 29 / 04$ & 241-U-102 & Headspace Sample & $<$ & 0.00022300 & $\mathrm{mg} / \mathrm{m} 3$ \\
\hline S23.1-5DM & DMHg-399 & $11 / 29 / 04$ & 241-U-102 & Headspace Sample & $<$ & 0.00021800 & $\mathrm{mg} / \mathrm{m} 3$ \\
\hline S22.1-4DM & DMHg-422 & $11 / 28 / 04$ & 241-U-108 & Headspace Sample & $<$ & 0.00004170 & $\mathrm{mg} / \mathrm{m} 3$ \\
\hline S22.1-5DM & DMHg-385 & $11 / 28 / 04$ & 241-U-108 & Headspace Sample & $<$ & 0.00004080 & $\mathrm{mg} / \mathrm{m} 3$ \\
\hline S18.1-4DM & DMHg-365 & $11 / 19 / 04$ & 241-U-201 & Headspace Sample & $<$ & 0.00000197 & $\mathrm{mg} / \mathrm{m} 3$ \\
\hline S18.1-5DM & DMHg-368 & $11 / 19 / 04$ & $241-U-201$ & Headspace Sample & $<$ & 0.00000197 & $\mathrm{mg} / \mathrm{m} 3$ \\
\hline S19.1-4DM & DMHg-410 & $11 / 19 / 04$ & $241-U-202$ & Headspace Sample & $<$ & 0.00000186 & $\mathrm{mg} / \mathrm{m} 3$ \\
\hline S19.1-5DM & DMHg-408 & $11 / 19 / 04$ & 241-U-202 & Headspace Sample & $<$ & 0.00000182 & $\mathrm{mg} / \mathrm{m} 3$ \\
\hline S20.1-4DM & DMHg-380 & $11 / 23 / 04$ & $241-U-203$ & Headspace Sample & $<$ & 0.00000168 & $\mathrm{mg} / \mathrm{m} 3$ \\
\hline S20.1-5DM & DMHg-378 & $11 / 23 / 04$ & 241-U-203 & Headspace Sample & $<$ & 0.00000172 & $\mathrm{mg} / \mathrm{m} 3$ \\
\hline S78.1-4DM & & $01 / 26 / 05$ & 241-U-101 & Headspace Sample & $<$ & 0.00003700 & $\mathrm{mg} / \mathrm{m} 3$ \\
\hline S28.1-5DM & & $01 / 26 / 05$ & 241-U-101 & Headspace Sample & $<$ & 0.00003300 & $\mathrm{mg} / \mathrm{m} 3$ \\
\hline S27.1-4DM & DMHg-459 & $01 / 24 / 05$ & 241-U-106 & Headspace Sample & $<$ & 0.00000200 & $\mathrm{mg} / \mathrm{m} 3$ \\
\hline S27.1-5DM & & $01 / 24 / 05$ & $241-U-106$ & Headspace Sample & $<$ & 0.00000200 & $\mathrm{mg} / \mathrm{m} 3$ \\
\hline S34.1-7DM & DMHg-521 & $02 / 23 / 05$ & 241-SX-108 & Headspace Sample & $<$ & 0.00000200 & $\mathrm{mg} / \mathrm{m} 3$ \\
\hline S34.1-8DM & DMHg-526 & $02 / 23 / 05$ & 241-SX-108 & Headspace Sample & $<$ & 0.00000200 & $\mathrm{mg} / \mathrm{m} 3$ \\
\hline S35.1-7DM & DMHg-532 & $02 / 23 / 05$ & 241-SX-110 & Headspace Sample & $<$ & 0.00000200 & $\mathrm{mg} / \mathrm{m} 3$ \\
\hline S35.1-8DM & DMHg-529 & $02 / 23 / 05$ & 241-SX-110 & Headspace Sample & $<$ & 0.00000200 & $\mathrm{mg} / \mathrm{m} 3$ \\
\hline S38.1-7DM & DMHg-488 & $03 / 04 / 05$ & 241-A-105 & Headspace Sample & $<$ & 0.00002400 & $\mathrm{mg} / \mathrm{m} 3$ \\
\hline S38.1-8DM & DMHg-502 & $03 / 04 / 05$ & 241-A-105 & Headspace Sample & $<$ & 0.00001500 & $\mathrm{mg} / \mathrm{m} 3$ \\
\hline S36.1-7DM & DMHg-520 & $02 / 24 / 05$ & 241-SX-114 & Headspace Sample & $<$ & 0.00000200 & $\mathrm{mg} / \mathrm{m} 3$ \\
\hline S36.1-8DM & DMHg-511 & $02 / 24 / 05$ & 241-SX-114 & Headspace Sample & $<$ & 0.00000200 & $\mathrm{mg} / \mathrm{m} 3$ \\
\hline S33.1-4DM & DMHg-467 & $02 / 14 / 05$ & 241-S-104 & Headspace Sample & $<$ & 0.00000200 & $\mathrm{mg} / \mathrm{m} 3$ \\
\hline S33.1-5DM & DMHg-465 & $02 / 14 / 05$ & 241-S-104 & Headspace Sample & $<$ & 0.00000200 & $\mathrm{mg} / \mathrm{m} 3$ \\
\hline S37.1-7DM & DMHg-509 & $02 / 28 / 05$ & 241-A-104 & Headspace Sample & $<$ & 0.00000200 & $\mathrm{mg} / \mathrm{m} 3$ \\
\hline S29.1-4DM & DMHg-437 & $02 / 07 / 05$ & 241-S-107 & Headspace Sample & $<$ & 0.00004200 & $\mathrm{mg} / \mathrm{m} 3$ \\
\hline S24.1-4DM & DMHg-382 & $12 / 15 / 04$ & 241-U-103 & Headspace Sample & $<$ & 0.00022500 & $\mathrm{mg} / \mathrm{m} 3$ \\
\hline S32.1-4DM & $\mathrm{DMHg}-480$ & $02 / 17 / 05$ & 241-S-109 & Headspace Sample & $<$ & 0.00000200 & $\mathrm{mg} / \mathrm{m} 3$ \\
\hline S25.1-5DM & DMHg-395 & $12 / 20 / 04$ & 241-U-110 & Headspace Sample & $<$ & 0.00002610 & $\mathrm{mg} / \mathrm{m} 3$ \\
\hline S26.1-5DM & DMHg-452 & $12 / 27 / 04$ & 241-U-105 & Headspace Sample & $<$ & 0.00025300 & $\mathrm{mg} / \mathrm{m3}$ \\
\hline S24.1-5DM & DMHg-381 & $12 / 15 / 04$ & 241-U-103 & Headspace Sample & $<$ & 0.00019100 & $\mathrm{mg} / \mathrm{m} 3$ \\
\hline S32.1-5DM & DMHg-481 & $02 / 17 / 05$ & 241-S-109 & Headspace Sample & $<$ & 0.00000200 & $\mathrm{mg} / \mathrm{m} 3$ \\
\hline S37.1-8DM & DMHg-504 & $02 / 28 / 05$ & 241-A-104 & Headspace Sample & $<$ & 0.00000200 & $\mathrm{mg} / \mathrm{m3}$ \\
\hline S31.1-4DM & DMHg-465 & $02 / 04 / 05$ & 241-S-103 & Headspace Sample & $<$ & 0.00000200 & $\mathrm{mg} / \mathrm{m} 3$ \\
\hline 043264-RDM-001 & DMHg-331 & $12 / 02 / 04$ & SY Ventilation & Headspace Sample & $<$ & 0.00000010 & $\mathrm{mg} / \mathrm{m} 3$ \\
\hline S25.1-4DM & DMHg-463 & $12 / 20 / 04$ & $241-U-110$ & Headspace Sample & $<$ & 0.00002800 & $\mathrm{mg} / \mathrm{m} 3$ \\
\hline S26.1-4DM & DMHg-446 & $12 / 27 / 04$ & $241-U-105$ & Headspace Sample & $<$ & 0.00024800 & $\mathrm{mg} / \mathrm{m} 3$ \\
\hline
\end{tabular}

